\title{
Multiple cryptic refugia of forest grass Bromus benekenii in Europe as revealed by ISSR fingerprinting and species distribution modelling
}

\author{
Agnieszka Sutkowska $\cdot$ Andrzej Pasierbiński • \\ Tomasz Warzecha · Józef Mitka
}

Received: 6 June 2013 / Accepted: 15 December 2013/Published online: 3 January 2014

(c) The Author(s) 2014. This article is published with open access at Springerlink.com

\begin{abstract}
Despite not having been fully recognized, the cryptic northern refugia of temperate forest vegetation in Central and Western Europe are one of the most important in the Holocene history of the vegetation on the subcontinent. We have studied a forest grass Bromus benekenii in 39 populations in Central, Western and Southern Europe with the use of PCR-ISSR fingerprinting. The indices of genetic population diversity, multivariate, and Bayesian analyses, supplemented with species distribution modelling have enabled at least three putative cryptic northern refugial areas to be recognized: in Western Europe-the Central and Rhenish Massifs, in Central Europe-the Bohemia-Moravia region and in the Eastern/Western Carpathians. Central Poland is the regional genetic melting-pot where several migratory routes might have met. Southern Poland had a different postglacial history and was under the influence of an Eastern/Western Carpathian cryptic refugium. More forest species should be checked in a west-east gradient in Europe to corroborate the hypothesis on the Western European glacial refugia.
\end{abstract}

Electronic supplementary material The online version of this article (doi:10.1007/s00606-013-0972-x) contains supplementary material, which is available to authorized users.

A. Sutkowska $(\bowtie) \cdot$ T. Warzecha

Department of Plant Breeding and Seed Science, Agricultural University in Kraków, Łobzowska 24, 31-140 Kraków, Poland e-mail: asutkowska@ar.krakow.pl

\section{A. Pasierbiński}

Department of Plant Systematics, University of Silesia, Jagiellońska 28, 40-032 Katowice, Poland

\section{J. Mitka}

Institute of Botany, Botanic Garden, Jagiellonian University in Kraków, Kopernika 27, 31-501 Kraków, Poland
Keywords Bayesian analysis - Climate matching . Dispersal · Forest glacial refugia - Genetic structure . Melting pot $\cdot$ Postglacial history $\cdot$ LGM climate

\section{Introduction}

A key to understanding the origin of contemporary floras are glacial refugia, i.e. spots where some thermophilous elements could have survived. Certainly, they were located far south of the glacial front, therefore not affected by harsh climate. It is assumed that these refugia, which enabled the recolonization of Central Europe, were mainly in the Mediterranean area. It is widely accepted that the Balkan Peninsula played a significant role in the reconstruction of Central European flora (Taberlet et al. 1998), supplied continuous, at least from the Eemian interglacial, pollen records of trees such as Carpinus sp., Tilia sp., Ulmus sp. and Quercus sp. (Tzedakis et al. 2002).

In recent years, this view was supplemented by the concept of the northern cryptic refugia (Bhgawat and Willis 2008; Provan and Bennett 2008). This hypothesis stated that not only temperate-boreal, but also thermophilous temperate tree species, might have survived the last glacial maximum (LGM, pleniglacial, $\sim 21,000$ year BP) in refugial areas, "oases" in Central Europe, where sufficient warmth and humidity existed in small micro-environmental pockets (Willis et al. 2000). For example, Magri et al. (2006) and Magri (2008) postulated that Fagus sylvatica could survived the last pleniglacial in cryptic northern refugia in the open forests of Central Europe, including the southern Moravia and southern Bohemia and most probably the Eastern Carpathians. Moreover, the macroscopic charcoal records indicate the existence of thermophilous trees such as Carpinus betulus, Quercus sp., 
Corylus sp., Ulmus sp., and Tilia sp. in the Hungarian landscape during the LGM (Willis et al. 2000). Brewer et al. (2002) recognised primary, full-glacial refugia, and secondary, temporary refugia for Quercus sp., which supported populations of the termophilous trees during the short, climatically unfavourable, late-glacial Younger Dryas stadial. This picture, based on the fossil pollen data, is complemented by chloroplast DNA data (Bordács et al. 2002).

The retracing of the postglacial migration routes of taxa from refugia into the area left by the outgoing glacier is very important for understanding the history of the European Holocene flora. This has been confirmed by many phytogeographical studies on herbaceous plants and animals (Tyler 2002a, b; Kotlík et al. 2006; StachurskaSwakoń et al. 2012). The palaeobotanical data (studies of macrofossils and pollen analysis) are particularly important in the localization of refugia and in determining the postglacial migration routes of trees and shrubs (Ralska-Jasiewiczowa et al. 2003, 2004; Daneck et al. 2011). Unfortunately, there are few comparable studies for forest herbaceous plants because pollen grains are often taxonomically identified only to the genus level.

Some forest species were examined by means of enzyme electrophoresis, including Carex digitata, Melica nutans (Tyler 2002a, b) and Lathyrus vernus (Schiemann et al. 2000), and chloroplast DNA, including Alnus glutinosa (King and Ferris 1998), Hedera spp. (Grivet and Petit 2002), Carpinus betulus (Grivet and Petit 2003), and Fraxinus excelsior (Heuertz et al. 2004). All these studies show the importance of the glacial forest refugia in the mountains of southern (the Apennines and Balkans) and western (the Pyrenees) Europe in postglacial recolonization of central and northern Europe.

The molecular analysis of highly variable, non-coding regions of DNA (mini- and microsatellites) has contributed to the identification of past refugia of many European taxa, mainly alpine and subalpine. In the refugial populations an increased genetic divergence, accompanied by a high number of the rare alleles, could be expected from theoretical and empirical studies (Paun et al. 2008; Ronikier 2011), including genetic drift, different selection pressures and mutation (Tyler 2002a). Also, it is expected that the highest population genetic diversity of the forest plant species can be found in places where divergent lineages from separate refugia met in the "melting pots" at intermediate latitudes in Central Europe (Petit et al. 2003). However, repeated founder events and immigrations from different sources resulting from repeated long-distance dispersal may blur geographical variation patterns (Tyler 2002a).

In this study, we analysed the forest grass Bromus benekenii (Lange) Trimen in 39 populations from
Central, Western and Southern Europe to reveal geographic pattern of genetic variation using the PCR-ISSR protocol.

Bromus benekenii (Lange) Trimen (lesser Hairy-bromePoaceae $)$ is an allopolyploid $(2 n=28)$ species possessing a genome similar to the American species of subgen. Festucaria, described as the "L genome". B. benekenii is closely related to B. ramosus (Sutkowska et al. 2007; Sutkowska and Mitka 2008) and forms two geographical elements: the Holarctic (Euro-Siberian sub-element) and the Irano-Turanian, here with the center in mountain areas (Zajace and Zajacc 2009). It is an epizoochoric, cross-pollinated perennial forest grass.

We selected the species for its strict habitat preferences (Kožuharov et al. 1981) and the wide distribution typical to European, temperate forest herb species. It occurs mainly in Central and Eastern Europe, as well as in western Asia (Fig. 1c). Scarce populations of the species occur also in Western Europe (France, Germany, Switzerland, Italy, Austria), southern Scandinavia, the Caucasus and in the mountains of central Asia (Zajac and Zając 2009). B. benekenii in Europe is mainly a lowland species, although it may occur also in foothills and the lower mountain areas (Mirek and Piękoś-Mirkowa 2002). It is closely related to fertile beech forest and montane alderwood communities, and it prefers hummocky medium-moist habitats or medium light-exposed forest edges (Balcerkiewicz 2002). It can be also found in dry mesic oak forests on loess, dealpine mountain calcareous grassland, and in the synanthropic vegetation with a high requirement for nutrients or on lime (Šeffer et al. 2002; Roleček 2005).

The phylogeographic results were supported by the species distribution modelling (SDM, Guisan and Zimmermann 2000). The SDM techniques are based on statistical or mechanistic approaches to assess the relationship between species distribution and potential determinants with the use of a representative sample of occurrence data from its current geographical range, climatic data and Community Climate System Model (Collins et al. 2004).

In the present study, we performed the genetic analysis of $B$. benekenii for the following purposes: (1) to test whether the genetic structure of $B$. benekenii reflects the long-term isolation in putative "northern" refugia during the Quaternary; (2) to check a hypothesis on the regional "melting pots" where met several migration routs from various refugia; (3) to compare the inferred glacial refugia of $B$. benekenii with the putative refugial areas of some other forest plant species; (4) to reconstruct the potential distribution of B. benekenii in the LGM using SDM based on the palaeoclimatic scenario and current climatic data to support the main hypotheses. 


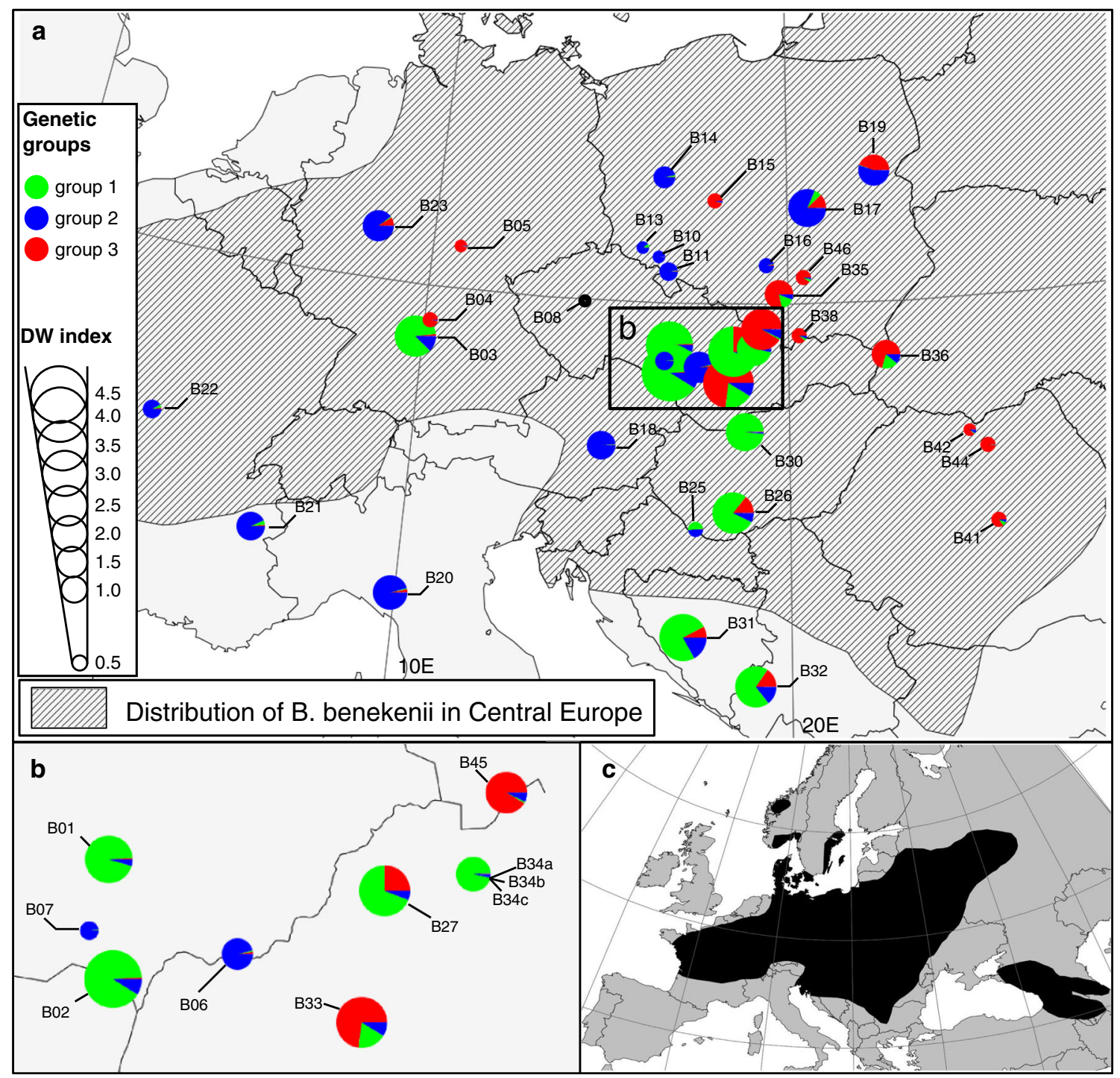

Fig. 1 a Geographical range of Bromus benekenii in Central Europe (hatched area) and location of 39 populations sampled-some of them are located in isolated populations outside the main range; b location of populations in the Czech Republic and Slovakia; c general distribution of $B$. benekenii in Europe, taken from Meusel et al. (1965-1992). The colours of the dots refer to the three ISSR genetic groups resolved using Bayesian analysis (Fig. 2). Size of circle is directly proportional to the rarity index $D W$ (see Table 1 for exact values)

\section{Materials and methods}

\section{Sampling}

Leaf material of 319 individual plants from 39 populations of B. benekenii was sampled across Western, Central and Southern Europe in Austria, Bosnia and Herzegovina, Czech Republic, France, Germany, Hungary, Italy, Montenegro, Poland, Romania, Slovakia and Slovenia (Fig. 1a, b; Table 1) in July-August 2011. Fragments of leaves were picked out from the individuals distributed in a minimum of $3 \mathrm{~m}$ distance from each other and then dried in silica gel. Voucher specimens were deposited in the herbarium of the Institute of Botany, Jagiellonian University in Kraków (KRA).

Species distribution modelling (SDM)

The main source of occurrence data used to models calibration was the GBIF database (http://www.gbif.org) and the Interactive Agricultural Ecological Atlas of Russia and Neighbouring Countries (http://www.agroatlas.ru). Data on the occurrence of species were also supplemented by numerous field studies carried out by the authors across the Europe. After removing duplicate records a total of 627 


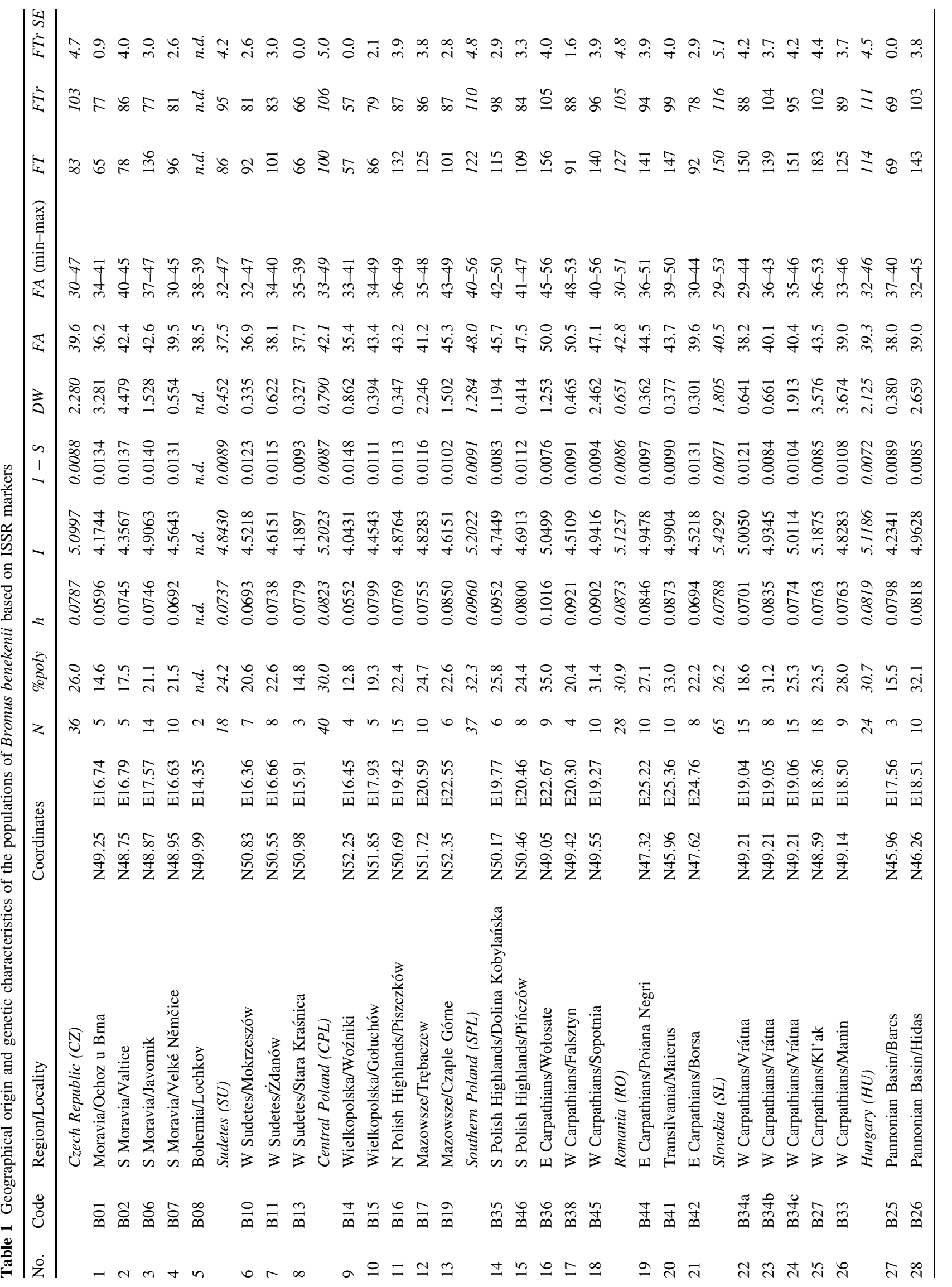




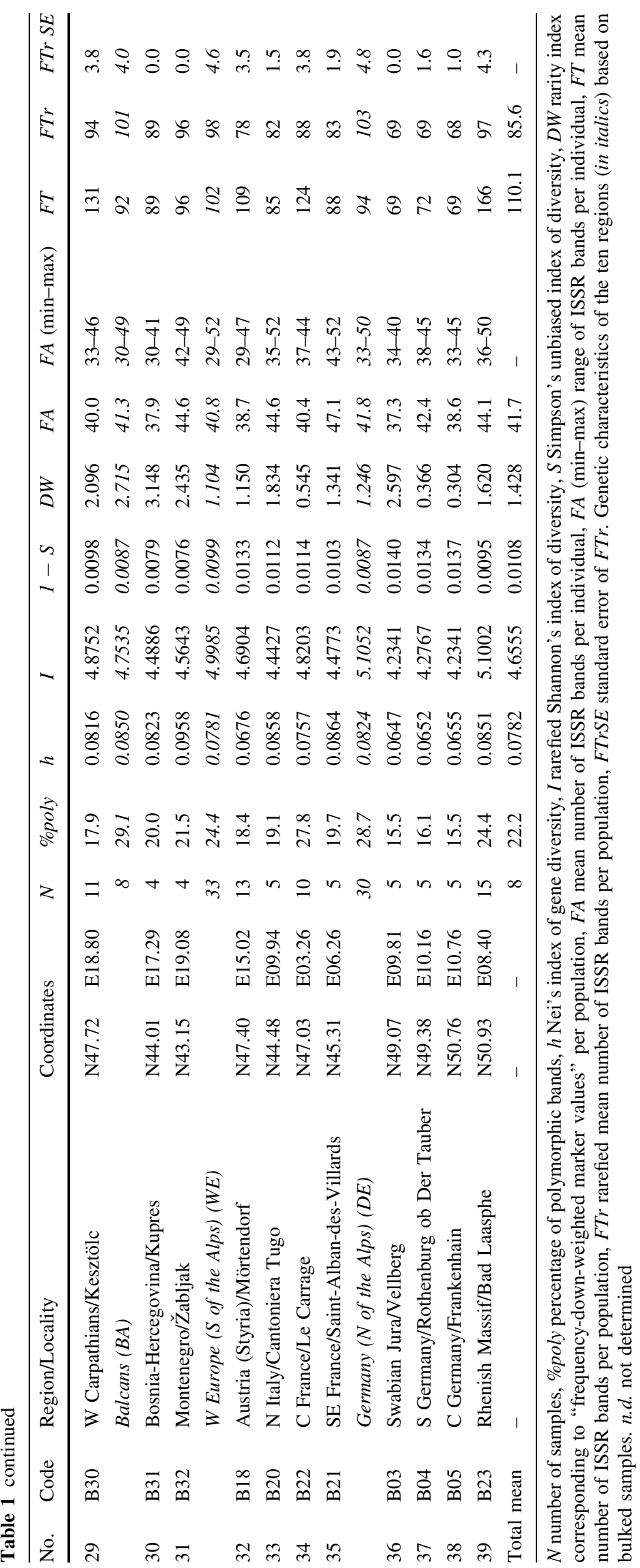


Fig. 2 The consensus BIOMOD projections of climatic niche of $B$. benekenii onto current climatic conditions (a) and past climate model CCSM (b), derived by median of models predictions. Darker areas represent higher probability of occurrence. The locations of occurrence records used in calibration and evaluation of models were also marked by white dots in a
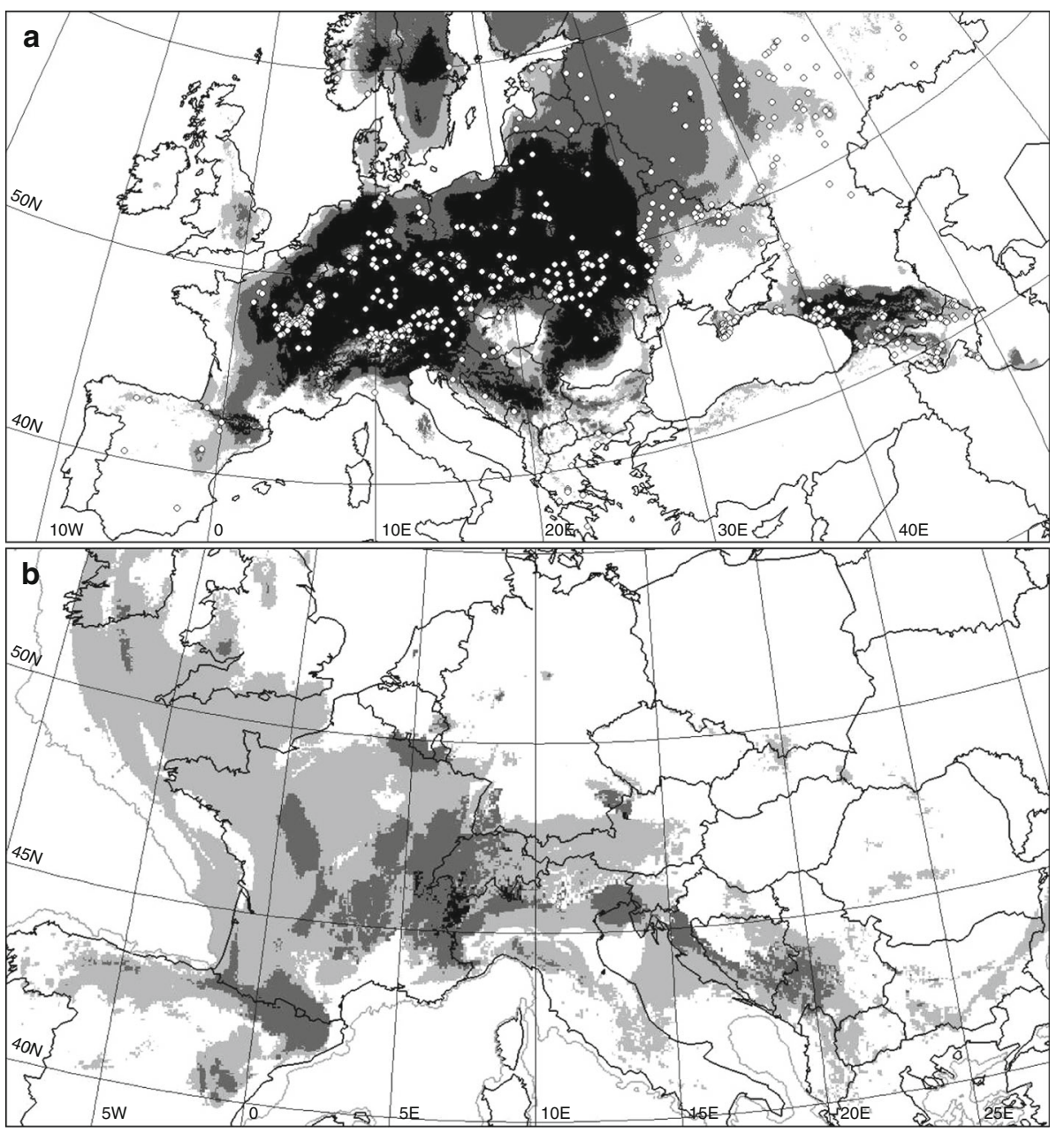

\begin{tabular}{l|l|l||l|l|l|}
\hline Probability of presence: & $<25 \%$ & $25-50 \%$ & $50-75 \%$ & $>75 \%$ \\
\hline
\end{tabular}

O Occurrence data of $\mathrm{B}$. benekeniiused in model calibration and evaluation

- Current coastline and administrative boundaries

Coastline in the last glaciation ( 21,000 years BP $)$ occurrences of $B$. benekenii were used for the calibration and evaluation of models (Fig. 2a)

The Community Climate System Model (CCSM, Collins et al. 2004) of past climate were used to project potential distribution in the LGM. Bioclimatic variables downscaled to $2^{\prime} 30^{\prime \prime}$ resolution were obtained from the WorldClim dataset (Hijmans et al. 2005, http://www. worldclim.org), together with present-day climate data at the same resolution. To avoid redundancy from a list of all original WorldClim layers we selected variables that were possibly weakly correlated with each other (Pearson's $r<0.7)$. Finally, we considered seven environmental variables as potential predictors of the $B$. benekenii distribution; namely: mean diurnal range of temperature, temperature seasonality, mean temperature of the wettest quarter, mean temperature of the driest quarter, precipitation seasonality, precipitation of the warmest quarter and precipitation of the coldest quarter. All environmental layers were cropped to the same area between $10 \mathrm{~W}-60 \mathrm{E}$ longitude and $35 \mathrm{~N}-75 \mathrm{~N}$ latitude and prepared using GRASS GIS software version 6.4 (http://grass.osgeo.org).

Recent comparative studies showed that different modelling techniques calibrated on the same species can produce different results (Elith et al. 2006), particularly when models are used to project distributions of species into independent climatic scenarios (Thuiller 2004). Therefore, we used nine different algorithms implemented in BIOMOD software version 1.1-7 (Thuiller et al. 2009); namely: Generalized Linear Models (GLM), Generalized Additive Models (GAM), Classification Tree Analysis (CTA), Artificial Neural Networks (ANN), Surface Range Envelope (SRE), Generalized Boosting Model (GBM), Random Forest for classification and regression (RF), Flexible Discriminant Analysis (FDA) and Multiple Adaptive Regression Splines (MARS). Models were run in 20 replicates, randomly selecting $70 \%$ of the point localities 
Table 2 The primers used in PCR, total number of ISSR bands (loci) generated by respective primer, Min.-Max - minimum and maximum number of ISSR bands per specimen, and mean number of ISSR bands per specimen

\begin{tabular}{lllll}
\hline Primer & $\begin{array}{l}\text { Primer } \\
\text { sequence }\end{array}$ & $\begin{array}{l}\text { Total no. } \\
\text { of bands }\end{array}$ & Min.-Max. & $\begin{array}{l}\text { Mean no. of } \\
\text { bands per } \\
\text { specimen }\end{array}$ \\
\hline ISSR1 & $(\mathrm{TC})_{8} \mathrm{C}$ & 1962 & $3-12$ & 6 \\
ISSR2 & $(\mathrm{AG})_{8} \mathrm{~T}$ & 2342 & $3-13$ & 7 \\
ISSR3 & $(\mathrm{GGGTG})_{3}$ & 2558 & $4-13$ & 8 \\
ISSR4 & $(\mathrm{ATG})_{6}$ & 1675 & $3-12$ & 5 \\
ISSR6 & $(\mathrm{AC})_{8} \mathrm{G}$ & 2274 & $3-12$ & 7 \\
ISSR7 & $(\mathrm{AC})_{8} \mathrm{~T}$ & 2233 & $4-12$ & 7 \\
\hline
\end{tabular}

assigned for training and $30 \%$ for testing each time. As only occurrences data were available, pseudo-absences were generated randomly to fill the absence component of the models. The predictive power of each model was tested using the area under the Receiver-Operating Characteristic (ROC) curve and Cohen's Kappa coefficient (Manel et al. 2001). Models calibrated with collected records of B. benekenii were projected onto current (Fig. 2a) and LGM ( 21,000 year BP, Fig. 2b) climatic conditions in Europe. We also performed ensemble forecasting (Thuiller et al. 2009) to generate final consensus models and to identify areas classified as suitable by the majority of the algorithms. This methodological approach allows one to eliminate artifacts generated by individual models and to identify areas classified as suitable by the majority of the SDM algorithms, particularly spatially isolated areas on the northern limits of the B. benekenii geographical range, which could constitute northern cryptic refugia.

\section{DNA extraction and ISSR analysis}

The Inter Simple Sequence Repeats (ISSR) method is based on highly polymorphic sequences of satellite DNA, consisting of a number of nucleotide sequences (microsatellite) tandemly repeated in thousands of copies. PCR reaction products are segments of DNA located between microsatellite regions and includes microsatellite sequences (Stepansky et al. 1999).

DNA was isolated from fully developed leaves without damage symptoms caused by insects, and mould. DNA was extracted with Genomic Mini AX Plant (A\&A Biotechnology). The core sequence of ISSR markers (Table 2) consisted of 2-5 repeats, in total 15-18 nucleotides in whole primer were used in PCR reaction (Stepansky et al. 1999). Amplification was carried out with a $25 \mu l$ reaction mixture comprising: a $2.5 \mu$ tenfold concentrated reaction buffer supplied by the Taq DNA polymerase manufacturer (Fermentas), $1.5 \mathrm{mM} \mathrm{MgCl}_{2}, 0.19 \mathrm{mM}$ of each dNTPs
(Fermentas), 27 pmol primer, $100 \mathrm{ng}$ template DNA and $1.4 \mathrm{U}$ of Taq polymerase (Taq DNA Polymerase (recombinant), Fermentas). Reactions were conducted with a 2720 thermal cycler (Applied Biosystems). The annealing temperature for primers ISSR2, ISSR4, ISSR 7 was $44{ }^{\circ} \mathrm{C}$, and for ISSR1, ISSR3, ISSR6 was $47^{\circ} \mathrm{C}$. Optimal conditions for the reaction were as follows: initial denaturation: $94{ }^{\circ} \mathrm{C}, 5 \mathrm{~min} ; 42$ amplification cycles: denaturation $94{ }^{\circ} \mathrm{C}$, $59 \mathrm{~s}$; annealing $44^{\circ} \mathrm{C}\left(47^{\circ} \mathrm{C}\right), 59 \mathrm{~s}$; elongation $72^{\circ} \mathrm{C}$, $59 \mathrm{~s}$; final elongation $72{ }^{\circ} \mathrm{C}, 7 \mathrm{~min}$.

A negative control reaction without a DNA template was included in each amplification. Products were subjected to electrophoresis in $1.5 \%$ agarose gel stained with ethidium bromide $(50 \mu \mathrm{l} / 100 \mathrm{ml})$ at $100 \mathrm{~V}$ for about $1.5 \mathrm{~h}$. Bands were observed and archivised with an Imagemaster VDS (Pharmacia, Amersham). Original software Liscap Capture version 1.0 was also applied.

For analysis of band patterns a GelScan version 1.45 (Kucharczyk TE) software was used (http://www.web statsdomain.com/tags/gelscan/). Thanks to the opportunity to create a calibration curve based on the band pattern of markers lengths (GeneRuler TM $100 \mathrm{bp}$, Fermentas), it was possible to determine the molecular weight of the resulting amplification products. ISSR reproducibility tests (Bonin et al. 2004) included within plate $(n=12)$ and between plate $(n=9)$ replicates independently analysed from the DNA extracts.

\section{Data analysis}

The amplification products were scored as a presence/ absence matrix of binary data. Percentage of the polymorphic bands (\%Pol) and Nei's (1973) gene diversity index $(h)$ were computed in accordance with the Bayesian method based on a non-uniform prior distribution of allele frequencies (Krauss 2000), implemented in an AFLP-surv version 1.0 (Vekemans et al. 2002). Shannon's index of diversity $I$ and total number of fragments (bands) per population $F T$ are sensitive to the number of sampled individuals (Kučera et al. 2008). The rarefaction technique was used to estimate the expected allelic richness at a locus for a fixed sample size. The rarefaction was made using $\mathrm{R}$ software (http://www.r-project.org). Rarefied probabilities served as a basis for the calculation of Shannon's index $I$ and Simpson's index $S$. The Simpson's $1-S$ is equivalent to Nei's gene diversity $h$ and represents the probability that two randomly selected alleles in a population are different. We calculated the rarefied allelic richness for two individuals, an unbiased estimator of $S$ index, according to Hurlbert (1971). The mean number of bands per individual in a population $F A$ was calculated and the rarity index $D W$, corresponding to "frequency-down-weighted marker values" per population (Schönswetter and Tribsch 2005) was 
computed using AFLPdat (Ehrich 2006). The $D W$ marker values were calculated as a number of occurrences of a marker in the population divided by the occurrences of that marker in the entire data set. Finally, these values were summed up and corrected for the total number of markers and individuals (Ehrich 2006). High $D W$ values are expected in long-term isolated populations (Paun et al. 2008).

The correlations between genetic diversity indices and sample size were tested using Pearson's correlation coefficient. The differences in molecular variability among geographic and genetic groups were tested with KruskalWallis $H$ test. The calculations were carried out with STATISTICA 10 (http://www.statsoft.com).

The genetic portioning among 319 individuals in 39 populations of $B$. benekenii was estimated by means of STRUCTURE, version 2.3.3 (Pritchard et al. 2000), applying a Bayesian model-based clustering algorithm for the use of dominant markers (Falush et al. 2007). The numbers of $K=2-10$ groups were tested in five replications per each $K$. A burn-in period 200,000, followed by 1 million Markov chain Monte Carlo (MCMC) repetitions were used. An admixture model with uncorrelated allele frequencies was applied. The dominant ISSR data were analysed by treating each class of genotypes as being, effectively, haploid alleles, according to the software documentation. The estimation of the optimal number of groups was based on the likelihood of partitions, estimates of posterior probability provided in STRUCTUTRE output, examined as a function of increasing $K$ (Pritchard et al. 2000) and $\Delta K$ values, estimating the change in the likelihood function with respect to $K$ and estimated as an indicator of the most reliable clustering structure (Evanno et al. 2005). A model-based algorithm implemented in the program STRUCTURE was calculated on a mega computer at the Bioportal at the University of Oslo (http://www.bio portal.uio.no). Similarity between runs was estimated using the symmetric similarity coefficient (Nordborg et al. 2005) with Structure-sum R-script (Ehrich 2006).

The genetic structure of populations and variation levels were assessed by an analysis of molecular variance (AMOVA; Excoffier et al. 1992). Significance levels were determined using 1,023 permutations. The permutations were carried out at three different hierarchic levels: within populations, among populations and among groups of populations (geographical groups of populations based on a priori 10 geographical regions and detected by Bayesian analysis for $K=3$ ), calculated with Arlequin 3.5 (Excoffier and Lischer 2010).

A neighbour-net diagram was based on the population matrix of Nei \& Li genetic distances and bootstrapped using 1000 replicates with SPLITSTREE 4.12 software (Huson and Bryant 2006). A principal coordinate analysis (PCoA) was performed using simple matching similarity coefficient (Sokal and Michener 1958) with NTSYSpc version 2.11 (Rohlf 2002). Hallden et al. (1994) considered the simple matching coefficient to be the more appropriate measure of similarity when closely related taxa are considered. The minimum spanning tree among regions was computed with NTSYSpc. The rarefied frequency data were angular transformed according to the formula $x^{\prime}=\operatorname{SQRT} \operatorname{ARCSIN}(x)$.

\section{Results}

Prediction of LGM distributions

The most common method of model evaluation is the threshold-independent Area Under the Curve (AUC) of the receiver operating characteristic (ROC) plot. The AUC values obtained for individual models ranged from 0.86 to 0.95. According to the criteria described by Swets (1988), AUC values between 0.8 and 0.9 are considered to indicate good models, and values between 0.9 and 1 -excellent models. Among the models, the RF model achieved the highest mean AUC and Kappa values (0.94 and 0.74, respectively). The AUC scores greater than 0.9 were also achieved by the GAM, GBM, FDA and MARS models. Because of the large number of results, only the final consensus models derived by the median of the models predictions are presented here.

The final consensus projection onto LGM climatic scenario identified the most suitable conditions (probability $>0.75$ ) only in the western Alps and Savoy. The areas with a predicted probability of over 0.5 are mainly located in the Rhone valley, Massif Central, in the Pyrenees, Lower Austria, Julian Alps and on the Balkan Peninsula, and along the Dinaric Alps. The majority of the SDM also predicted small, isolated areas with suitable conditions on the northern limits of potential range: in the Rhenish Massif, the Harz Mountains and in the valley of the Danube River, and on the eastern limits, with moderate probability, in several places in the Carpathians (Fig. 2b).

Genetic diversity within- and among-populations

PCR-ISSR analysis resulted in 446 polymorphic markers obtained from 319 individuals in 39 populations. The number of bands generated by particular primers per individual varied from 3 to 13 , with a mean ranged from 5 to 8 (Table 2). Data quality tests indicated a high repeatability across of the ISSR bands of above $97 \%$. The individual number of markers ranged from 29 (B34, Slovakia) to 56 (B36, southern Poland) with a mean of 41.7 (5.2 SD). The total (rarefied) number of bands per population Ftr was the lowest (57) in B14 from the central 


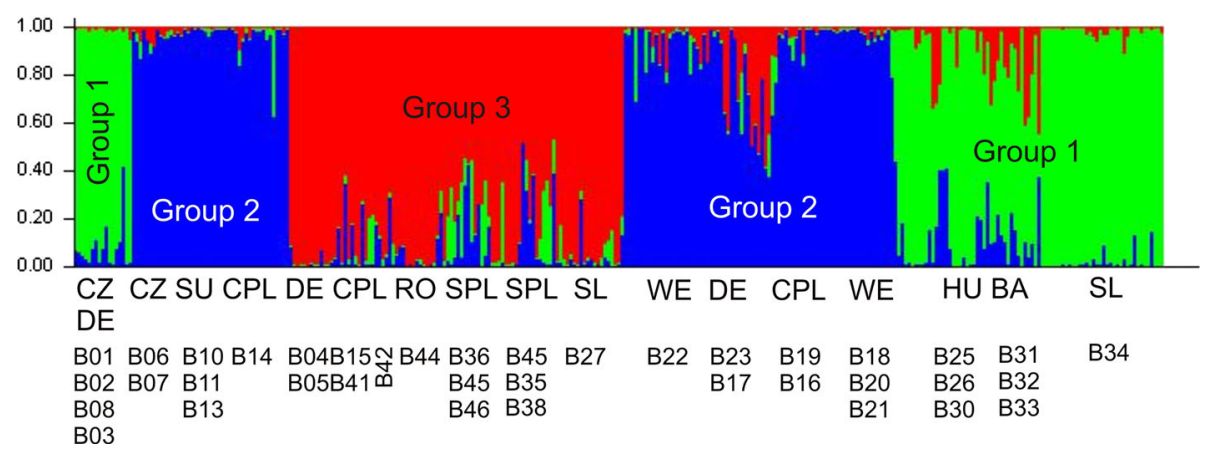

Fig. 3 Graphical output of the Bayesian analysis of the populations of Bromus benekenii using STRUCTURE software for $K=3$. Ten geographical regions: $C z$ Czech Republic, $S U$ Sudetes (Polish part), $C P L$ central Poland, SPL southern Poland, $R O$ Romania, SL Slovakia,

Poland, and the highest (105) in B36 from the Polish E Carpathians. The percentage of polymorphic markers \% Pol varied from $12.8 \%$ (B14, central Poland) to $35.0 \%$ (B36, southern Poland). For the whole data set, genetic diversity $1-S$ varied from 0.0076 (B32, Balkans and B36, Poland) to 0,0148 (B14, central Poland) and Shannon's $I$ index from 5.1875 in B27 (Slovakia) to 4.0431 in B14 (central Poland). The $D W$ coefficient ranged from 0.301 (B42, Romania) to 4.479 (B02, Czech Republic).

The rarefaction procedure decreased the correlation (Pearson's coefficient) between total number of bands per population and population size from $r=0.85$ for raw data to $r=0.52$ for rarefied data. The correlation between the Nei's gene diversity $h$ (with AFLPsurv) and Simpson's index of diversity $1-S$ equaled $r=-0.85$. The rarity index $D W$ was not significantly $(p>0.05)$ correlated with any of the genetic diversity measures, as well as with the sample size. The rarefied number of bands per population $F T r$ was correlated with $1-S$ index of diversity $(r=$ $-0.74)$. The mean number of bands per population was weakly correlated with the rarefied mean number of bands per population $(r=0.52, p>0.05)$. The percentage of polymorphic loci \%Pol and Shannon's index I were highly correlated with the rarefied number of bands per population, $r=0.84$ and $r=0.89$, respectively. All these correlations had a significance level at $p<0.001$.

The Kruskal-Wallis $H$ tests gave significant results for the genetic structuring of 38 (excluding B08) populations among 10 geographic regions for the three indices: individual number of bands $F A(p=0.0223)$, rarefied number of bands per population $F \operatorname{Tr}(p=0.0339)$, and $1-S(p=0.0082)$.

Genetic relationships among regions and STRUCTURE groups

Bayesian groupings of individuals provided a confirmation of the above results. In the STRUCTURE analysis, the
$H U$ Hungary, BA Balkans (Bosnia and Hercegovina, Montenegro), $W E$ Western Europe (Austria, France, Italy), DE Germany. Group colours are the same as in Fig. 1

optimal $\Delta K$ and the highest similarity coefficient $(0.86 \pm 0.06 \mathrm{SD})$ were given only to those runs in which $K=3$ (Fig. 1S, Supported Materials). The results showed the existence of the three genetic groups in B. benekenii individuals, irrespective of the geographic population structure (Figs. 1, 3). The genetic Group 1 consisted of the Moravian-Bohemian B01, B02, B08, the German population from Swabian Jura B03, two populations from Slovakia (B33 and B34), and the populations from Hungary (B25, B26, B30) and the Balkans (B31 and B32). The genetic Group 2 consisted of two populations from southern Moravia B06 and B07, the Sudetes (B10, B11, B13), central Poland (B14-B17, B19), and Western Europe (Germany B23, Italy B20 and France B21 and B22). The genetic Group 3 had populations from Germany (B04, B05), central Poland (B15), Romania (B41, B42, B44), southern Poland (B45, B46), and Slovakia (B27).

The Kruskal-Wallis $H$ tests gave significant results for the genetic structuring of 38 (excluding B08) populations among the three genetic groups for the two indices: $F A$ $(p=0.0046)$ and $D W(0.0044) . F A$ index was the highest in the Group $3(44.7 \pm 0.94 \mathrm{SE})$, and the lowest in the Group 1 (39.4 $\pm 0.94 \mathrm{SE}) . D W$ index was the highest in the Group $1(2.33 \pm 0.29 \mathrm{SE})$, and the lowest in the Group 3 $(0.96 \pm 0.29 \mathrm{SE})$.

The results of AMOVA indicated a markedly higher proportion of variation within populations then between populations $\left(F_{\mathrm{ST}}=0.33\right.$, Table 3$)$. At the level of ten geographical regions, the variation among groups was $7.90 \%, 25.75 \%$ among populations within groups, and $66.35 \%$ within populations, with $F_{\mathrm{ST}}=0.33$. The three STRUCTRE groups yielded slightly lower variation among groups $6.74 \%, 27.85 \%$ within groups, with $F_{\mathrm{ST}}=0.34$.

The neighbour-net diagram confirmed the three genetic groups among the populations of $B$. benekenii (Fig. 4). Most of the groups was strongly supported within $87-100 \%$, and only the two groups were supported in 57 and $58 \%$. Within 
Table 3 Analysis of molecular variance (AMOVA) of Bromus benekenii for 39 populations, ten geographical regions, and three genetic groups

\begin{tabular}{lrrrr}
\hline Source of variation & $d f$ & Sum of squares & Variance components & Percentage of variation \\
\hline 1. Total & & & & $F_{\text {ST }}$ \\
$\quad$ Among all populations & 38 & 3184.329 & 8.26134 & 33.16 \\
Within populations & 280 & 4661.912 & 16.64969 & 66.84 \\
2. Ten geographical groups & & & & \\
Among groups & 9 & 1231.088 & 1.98153 & 7.90 \\
Among populations within groups & 29 & 1953.242 & 6.46070 & 25.75 \\
Within populations & 280 & 4661.912 & 16.64969 & 66.35 \\
3. Three groups as in STRUCTURE & & & & 6.33 \\
Among groups & 2 & 537.914 & 1.71533 & 27.85 \\
Among populations within groups & 36 & 2646.416 & 7.08940 & 65.41 \\
Within populations & 280 & 4661.912 & 16.64969 & 0.34 \\
\hline
\end{tabular}

For all tests $p<0.001$

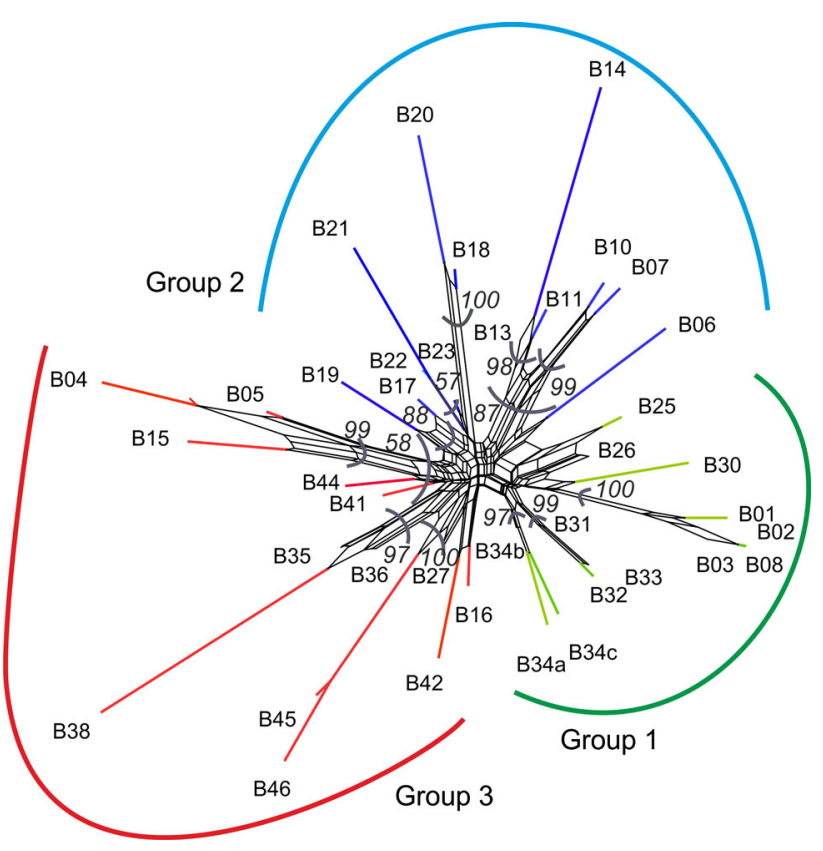

Fig. 4 Neighbour-net diagram of the Bromus benekenii populations based on the Nei \& Li coefficient. Codes of populations as in Table 1, the geographic regions as in Fig. 3. Bootstrap values $\geq 50$ are given. Group colours correspond to those in Fig. 3

the genetic Group 1 the highly supported (100\%) relationships between the Moravian-Bohemian B01, B02, B08 and the German population from Swabian Jura B03, and three Balkan's populations B31-B33, were found. Within the genetic Group 2 the highly supported were clusters: B17, B19 and B22 (100\%, C France-C Poland); B18 and B20 (100\%, Austria-Styria-N Italy); B11 and B14 (98 \%, Polish Highlands); B07 and B10 (99 \%, S Moravia and W Sudetes), which otherwise formed a bigger cluster moderately supported with $87 \%$. A moderately ( $88 \%$ ) supported populations were B17 and B19, both from C Poland. Within the
Group 3 the populations B23, B45 and B46 (100\%, Slovak and Polish W Carpathians, and Polish Highlands); B35, B36 and B38 (97 \%, Polish Carpathians and S Uplands); Bo4, B05 and B15 (99\%, Germany-C Poland).

The PCoA ordination analysis at the individual level confirmed the weak structuring of the data set. Individuals from different regions are scattered along Axis 1 and 2, points to their internal heterogeneity (Fig. 5a). Only individuals from three regions: Balkans, Hungary and Romania are relatively genetically homogenous. The first axis delimited mainly the Balkans, Hungary and most of Slovak and Czech populations, and on its right side, southern Poland (B45, B46) and Slovakia (B27). An intermediate position had the Sudetes and a part of the Czech populations. The second and third axes delimited Romania, a part of southern Poland (B36, B38), central Poland (B14) and Germany (B04, B05). An intermediate position along the second axis had most individuals from central Poland and Western Europe. The genetic Group 1 of the STRUCTURE analysis was the most homogenous (Fig. 5b). The genetic Group 3 was divided into the two parts. One of them consisted of southern Poland and Slovakia. The diagram showed a clear genetic STRUCTURE difference within the Czech (CZ) populations that belong to the Genetic groups 1 and 2 (the lower part of the diagram) and similarity between the Slovak (SL) and southern Polish (SPL) populations within the Group 3 (Fig. 5a, b).

A PCoA with a minimum spanning tree calculated at the geographic regional level showed the distinctiveness of the Balkan, Hungarian and Sudetic territory and the existence of two nodes (Fig. 6). The first was formed by Slovakianarea populations connected with the Balkan and southern Poland. The Slovakian node was linked also with the central Polish territory, which formed the second node, here cross links to Romania, Germany, and the Czech Republic. In the same cluster Germany was connected with Western Europe (Italy and Austria). 


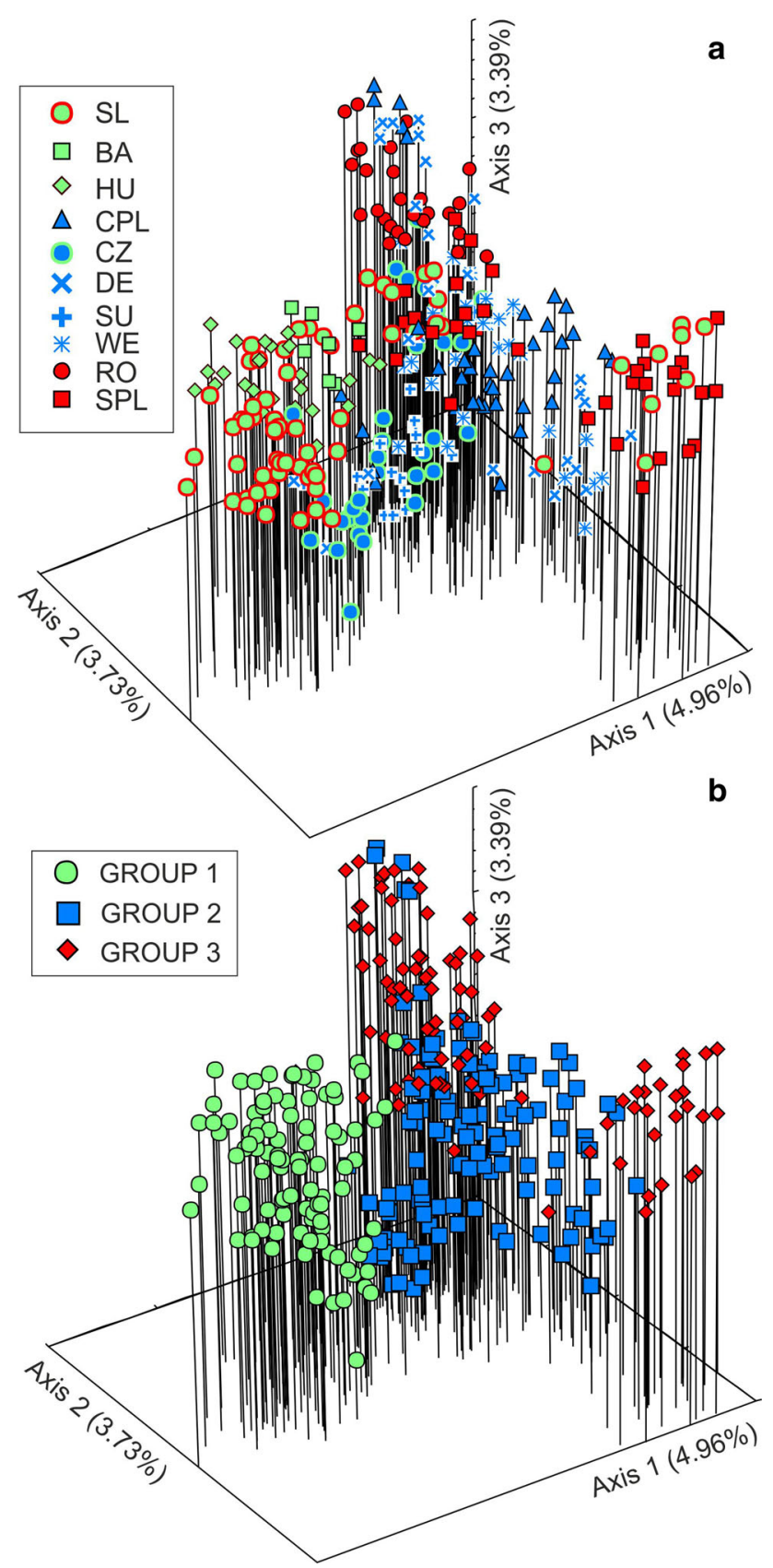

Fig. 5 Principal coordinate analysis (PCoA) of Bromus benekenii individuals based on simple matching coefficient. a Ten geographic regions, for their names see Fig. 3; b three genetic groups based on Bayesian analysis (see Fig. 3)

\section{Discussion}

Putative melting pots

Postglacial migrations of European biota are one of the most important issues in the historical biogeography of the Quaternary, as they shaped the present vegetation and geographical distribution of most animal and plant species.

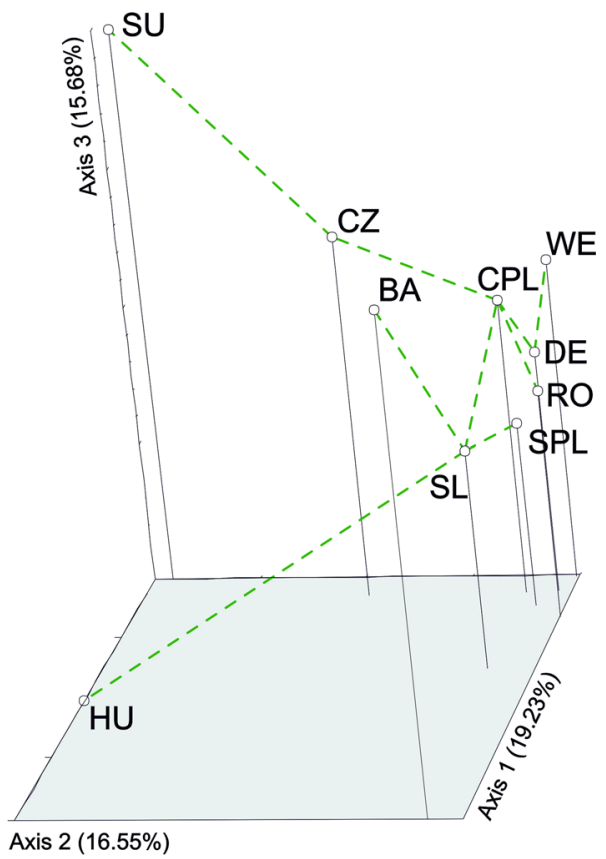

Fig. 6 Principal coordinate analysis (PCoA) of ten geographical regions of occurrence Bromus benekenii with minimum spanning tree (MST) imposed. Stress $2=0.07312$

DNA variation, both for tree and non-tree species, is a very informative way to investigate postglacial colonization. In the case of $B$. benekenii, it should be acknowledge as a wind pollinating forest grass, having dispersed by epizoochory. We found three genetic groups of the populations concordant with the regional geographic level. We hypothesised that they have various phylogeographic status including putative glacial refugia and melting pots, i.e. regions where postglacial migratory routs met (Taberlet et al. 1998). The status of a region could be inferred from the a priori expectations or assumptions. For example, it is expected the generally high genetic richness of the populations in European contact zones (Petit et al. 2003). Such a pattern was found for example in Quercus in Scandinavia, where the marginal northern occurrence of the species was independently colonised from two varying directions (Ferris 1998), and in the present paper in B. benekenii in central Poland (B17, B19) and Germany (B23). Those three "northern" populations are scattered among other having low values of genetic richness within $50-52^{\circ}$ of latitude. All they were probably outside refugial areas and represent newly established Holocene populations with relatively high values of genetic indices $I, F A$ and $D W$. The tentative explanation could their origin by hybridization between different genetic lineages that originated from different refugia (Walter and Epperson (2001). The first refugium was located probably in W Europe (Genetic Group 2) and the second in the Carpathians area (Genetic Group 3). 
Otherwise, it seems a rule that in refugial areas the occurrence of rare, "endemic" private alleles is high (Paun et al. 2008), as for example in a subalpine Aconitum bucovinense at the range margin in the Eastern Carpathians (Boroń et al. 2011).

Putative glacial refugia

The numerical analyses of the populations of $B$. benekenii in Central Europe clearly distinguished the three genetic groups assembled from various regions. They likely represent the different glacial-interglacial migration histories. In addition, the genetic/geographic groups are differentiated in respect of the genetic diversity indices and their distribution fits to the results of climatic reconstructions. It makes their interpretation more plausible and enables the generation of relevant phylogeographic hypotheses.

The most conspicuous findings concern the genetic Group 1, presumably refugial, consisted of the BohemianMoravian populations B01, B02, B08 and the German population B03, sharing seven bands. The group is genetically homogenous, supported in $100 \%$, and possesses one of the highest values of the rarity $D W$ index (2.597-4.479). A high value of rarity index $D W$ is often related to the refugial status of a population. The genetic Group 1, including the three Bohemian-Moravian populations plus German population B03, has the highest (and statistically significantly different) value of the $D W$ index, in comparison to the remaining groups. It suggests the existence of a massive cryptic northern forest grass refugium in the Moravian Highlands.

One of the earliest record of the Holocene beech expansion in Central Europe comes from sites located in the Moravian Highlands (southern Moravia) and southern Bohemia, where beech was sporadically present c. 10,200 year BP and attained $2 \%$ isopollen a 1,000 years later (Magri et al. 2006). Then, a rapid expansion of the species towards the western border of the central Bohemian basin and towards the Western Carpathians $6-5 \mathrm{kyr}{ }^{14} \mathrm{C}$ bp was noted (Magri 2008). According to Latałowa et al. (2004) Fagus could have reached southwestern Poland via slow migration from the Czech and Moravia lands into the Sudetes and to the Western Carpathians. Thus, most probably $B$. benekenii could have survived in the southern Moravian-southern Bohemian refugium and then expanded, through the Moravian Gate, to the Sudetes and central Poland. The postulated migration and colonization of new areas was accompanied by repeated bottlenecks that typically lead to reduced genetic diversity northward, a "leading edge" model (Hewitt 1999). Such a phenomenon was found for Fagus in Poland (Sułkowska et al. 2012). Also, the glacial Moravian refugium (Českomoravské mezihoří Hills, Českomoravska vrchovina Hills) was postulated for a forest shrub Lonicera nigra (Daneck et al. 2011). Also, the German population B03 from the Swabian Jura seems also to be refugial, however, more populations from the region should be analysed to make a statement more conclusive.

The next subgroup within the genetic Group 1 was formed by the populations from Slovakia (B34), Pannonia/ Carpathians (B25, B26, and B30, Hungary), and the Balkan countries (B31 and B32), with no common bands. It is a very uniform genetic group that seems to represent also refugial populations. It is characterized by high values of the genetic diversity indices, especially $F T r$ index. Generally, the Balkans, Carpathians and adjoining Carpathian Basin were shelter for Quercus sp. (Bordács et al. 2002). According to Hendrych and Hendrychová (1979) the migrations from the southern areas were one of the most important ways by which the forest flora of Slovakia was enriched in the postglacial period. However, we cannot rule out that the forest grass could have survived the LGM in the Slovak Carpathians, or more south, in the Pannonian Basin.

The genetic Group 2 group consists of the two subgroups. The first, supported in $87 \%,(\mathrm{PCoA})$ is formed by the populations: B07 (S Moravia), B10, B11, B13 (the Sudetes), and B14 (central Poland), sharing nine bands. These populations, opposite to the previous group, had low values of genetic diversity. Their phylogeographic status is unclear. Most probably they represent secondary populations originated from an unrecognized forest refugium.

The second subgroup consists of two populations B17 and B19 from central Poland, four populations B18, B20, B21, B22 from Western Europe and one population from the Rhenish Massif (B23, Germany). The populations from central Poland, the Rhenish Massif and central France shared five bands. We tend to speculate that genetic richness of the German B23, and possibly the French B21, as well as B18 from Austria and B20 from N Italy, is the effect of their refugial status ( $F A$ 38.7-47.1, $D W$ 1.341-1.834). In our opinion they represent unrecognized forest refugia in Western Europe, including the Rhenisch and Central Massifs (see CCSM model, Fig. 2b). The high genetic richness of the two central Polish populations B17 $(F A=41.2, D W=2.247)$ and $\mathrm{B} 19(45.3,1.502$, respectively) is clearly not the effect of their refugial status but rather a consequence of the admixture of divergent lines (a melting pot). First, $B$. benekenii could have migrated in the Holocene from the putative refugia north of the Alps, e.g. in Rhenish Massif (B23, Germany) eastwards. This direction roughly fits the postglacial migration for example of Carpinus betulus onto the Central European Lowlands (Ralska-Jasiewiczowa et al. 2003). Secondly, the forest species could have survived the LGM in the Eastern Carpathians and then migrated northwards to the Polish 
Highlands (see below) and, sporadically, to central-eastern Poland, for example the population B19. Such a southnorth migratory route in Poland was found for Picea abies and Quercus sp. (Dering et al. 2008).

The Massif Central is known as a refugial from other phylogeographic/palaeobotanic studies including Abies (Magri et al. 2006) and the tall-herb Cicerbita alpina (Michl et al. 2010).

The genetic Group 3 was formed by populations from different geographical regions. Here could be found populations from central and southern Poland, Romania, Germany and Western Europe. It seems a transitory group and represents presumably the expansion of the forest grass species from refugial areas or represents wide distribution of the similar genotype that could be the result of a previously continuous presence (Kotlík et al. 2006; Fér et al. 2007).

The first subgroup, highly supported (99\%), consists of two populations from central and southern Germany B04 and B05 and one population from central Poland B15. These populations have one the highest number of bands per individual $F A$. These index well-characterized regions were repeated long-distance dispersal from different sources (melting pot) could have occurred. This is an interesting group because it turns our attention to the possible migrations of the species in European lowlands north of the Alps. None of the populations could be shown as a source for the remaining ones because all of them have the same status in respect of their genetic diversity. In a study on AFLP genetic structure of Carpinus betulus in Europe a general trend of decreasing gene diversity $F T r$ and \%Pol was detected from east to west, i.e. away from the unrecognized Eastern European refugia (Coart et al. 2005).

The second subgroup is built of the populations from the Slovakian W Carpathians (B27), Romania (B41, B42, and B44), and southern Poland (B35, B36, B38, B45, and B46).

The existence of these two genetic and geographic subgroups clearly shows that the Polish populations from central and southern parts of the country had different postglacial histories and sources of origin. As the population from the central part of Poland has originated probably from the Moravian and $\mathrm{W}$ European regions, forming a melting pot, the Carpathian populations in southern Poland had sources in the Romanian E Carpathians and Slovakian W Carpathians. Such a pattern seems typical, taking into consideration the distinctness of the Carpathians as a refugial area for many alpine and subalpine species (2009, Ronikier 2011), Fagus (Liepelt et al. 2009), Lonicera (Daneck et al. 2011), Polygonatum (Kramp et al. 2009), and forest animals (Provan and Bennett 2008). Jankovská et al. (2002) report the sporadic presence of some climatically more demanding trees such as Corylus, Ulmus,
Quercus and Carpinus under a very cold continental climate during the LGM in the Slovakian W Carpathians. Similar results were obtained for other thermophilous organisms, including the forest rodent bank vole Clethrionomys glareolus (Kotlík et al. 2006) and a shrub Rosa pendulina L. (Fér et al. 2007).

\section{Species distribution modelling}

The results of species distribution modelling confirmed some results of PCR-ISSR molecular analysis. Postulated LGM refuges (inferred from the presence of rare alleles) of populations in the Balkans and in southern France were predicted with probability $>0.5$. Some of the results obtained by Svenning et al. (2008) using different LGM climate simulations (LMDZHR and S3P) and SDM methods confirm the high potential diversity of temperate species in these areas. They suggest that the view of the LGM landscape in Europe as largely treeless needs to be revised. Interestingly, most of the SDM performed on the CCSM climate reconstruction also identified suitable conditions for small scattered areas, e.g. in the Rhenish Massif (from which the B23 population comes), in the Harz Mountains and in the Danube valley (Fig. 2b). Putative refuges of B. benekenii in the Romanian Eastern Carpathians and Slovak Western Carpathians were also predicted, albeit with a lower probability $(0.25-0.5)$. The projection onto CCSM climate reconstruction predicted the highest probability of species presence $(>0.75)$ only in small areas in the northern-western Alps. This result is somewhat surprising since there is evidence that this area was under an ice cap (Kelly et al. 2004). It may be due to the fact that the palaeoclimatic scenario used in these studies was downscaled from coarse-grained outputs of the climatic scenarios provided by general circulation model. Statistical downscaling usually combines macroclimatic anomalies between past and current conditions with current highresolution climate data. Unfortunately, there is no general agreement about the best way of downscaling these simulations to properly define the relationship between largeand local-scale climate variables (Varela et al. 2011). Generally, these results suggest a strong relationship of B. benekenii occurrence to the mountainous areas and foothills in LGM. Longitudinal arrangement of the main mountain ranges in Europe may promote the survival of temperate species, particularly on slopes with a southerly exposure; moreover higher precipitation in higher altitudes could support preference of forest species for mountain areas. While comparing the present results with those of Leroy and Arpe (2007, Fig. 6b), it is clear that the distribution of the thermophilous deciduous trees (i.e. for those whose limiting factor is a minimum temperature $>2.5^{\circ} \mathrm{C}$ ) is more geographically restricted and confined to a few 
locations in Southern and Western Europe. These locations include about 10 regions in the Iberian Peninsula, the Riviera, large parts of the Apennines and Ancona, Dalmatia, isolated pots in Greece and Thracia, as well as in southeastern Europe in portions of Turkey, including the east cost of the Black Sea.

\section{Concluding remarks}

In conclusion, the forest grass $B$. benekenii had probably multiple refugia in Western Europe (Massif Central, Rhenish Massif) and in Central Europe, including the MoravianBohemian area, $\mathrm{E}$ and $\mathrm{W}$ Carpathians. The refugia in Southern Europe in the Balkan Mountains were also predicted from the SDM modelling. The putative migratory routes of the forest grass species agree with the well-documented postglacial migrations of Carpinus and Fagus. The relationships between the central Polish and German/France populations seem to be linked with the migration of Carpinus from the western European refugia. However, the reverse migration from east to west along the European Lowlands is also highly probable from the putative forest refugia on the Podolian-Volhynian Highlands of the Ukraine (Szafer and Zarzycki 1972) or from the Eastern Carpathians (King and Ferris 1998; Magri et al. 2006; Liepelt et al. 2009; Ilnicki et al. 2011), forming typical melting pot. The migration of the grass to central Poland from the south-westerly direction, via the Moravian Gate, is probably linked with the Moravian-Bohemian refugium, well documented for Fagus (Magri et al. 2006; Magri 2008). From here the grass species could have migrated both to Poland as well as to Germany. Nevertheless, existence of a cryptic refugium in Germany cannot be ruled out and it could serve as source for some the central Polish populations.

In Poland the genetic structure of the populations was quite different in its southern vs. central parts. In southern Poland the influence of the Carpathians is obvious, including their both $\mathrm{E}$ and $\mathrm{W}$ parts. In central Poland postglacial migrations of $B$. benekenii converged and formed a mosaic of the genetic groups, forming typical melting pot. The results obtained encourages one to seek the forest glacial refugia in Central Europe with the use of other forest herbaceous species, to better formulate the hypotheses regarding their occurrence in the region.

Acknowledgments The study was financially supported by Ministry of Science and Higher Education/National Science Centre of the Poland (N N303 396136). We thank Anonymous reviewers for substantial help in the preparing of manuscript.

Open Access This article is distributed under the terms of the Creative Commons Attribution License which permits any use, distribution, and reproduction in any medium, provided the original author(s) and the source are credited.

\section{References}

Balcerkiewicz S (2002) Trawy w zbiorowiskach roślinnych [Grasses in plant communities]. In: Frey L (ed) Polska Księga Traw [Polish Book of Grasses], pp 125-139, Instytut Botaniki PAN, Kraków

Bhagwat SA, Willis KJ (2008) Species persistence in northerly glacial refugia of Europe: a matter of chance or biogeographical traits. J Biogeogr 35:464-482

Bonin A, Bellemain E, Bronken Eidesen P, Pompanon F, Brochmann C, Taberlet P (2004): How to track and assess genotyping errors in population genetics studies. Mol Ecol 13:3261-73

Bordács S, Popescu F, Slade D (2002) Chloroplast DNA variation of white oaks in northern Balkans and in the Carpathian Basin. For Ecol Manage 156:197-209

Boroń P, Zalewska-Gałosz J, Nowak A, Sutkowska A, Zemanek B, Mitka J (2011) Aconitum bucovinense Zapał. (Ranunculaceae) at the range margin: spatial population-genetic structure of the Carpathian endemic and its conservation. Acta Soc Bot Pol 80:315-326

Brewer S, Cheddadi R, Beaulieu de JL, Reille M, Data contributors (2002) The spread of deciduous Quercus throughout Europe since the last glacial period. For Ecol Manage 156:27-48

Coart E, Van Glabeke S, Petit RJ, Van Bockstaele E, Roldán-Ruiz I (2005) Range wide versus local patterns of genetic diversity in hornbeam (Carpinus betulus L.). Conserv Genet 6:259-273

Collins WD, Blackmon M, Bitz C, Bonan G, Bretherton CS (2004) The community climate system model: CCSM3. J Clim 19:2122-2143

Daneck H, Abraham V, Fér T, Marhold K (2011) Phylogeography of Lonicera nigra in Central Europe inferred from molecular and pollen evidence. Preslia 83:237-257

Dering M, Lewandowski A, Ufnalski K, Kędzierska A (2008) How far to the east was the migration of white oaks from the Iberian refugium? Silva Fennica 42:327-335

Ehrich D (2006) AFLPdat: a collection of R functions for convenient handling of AFLP data. Mol Ecol Notes 6:603-604

Elith J, Graham CH, Anderson RP, Dudik M, Ferrier S, Guisan A, Hijmans RJ, Huettmann F, Leathwick JR, Lehmann A, Li J, Lohmann LG, Loiselle BA, Manion G, Moritz C, Nakamura M, Nakazawa Y, Mc J, Overton C, Peterson AT, Phillips SJ, Richardson K, Scachetti-Pereira R, Schapire RE, Soberon J, Williams S, Wisz MS, Zimmermann NE (2006) Novel methods improve prediction of species' distributions from occurrence data. Ecography 29:129-151

Evanno G, Regnaut S, Goudet J (2005) Detecting the number of clusters of individuals using the software STRUCTURE: a simulation study. Mol Ecol 14:2611-2620

Excoffier L, Lischer HEL (2010) Arlequin suite version 3.5: a new series of programs to perform population genetics analyses under Linux and Windows. Mol Ecol Res 10:564-567

Excoffier L, Smouse PE, Quattro JM (1992) Analysis of molecular variance inferred from metric distances among DNA haplotypes: application to human mitochondrial DNA restriction data. Genetics 131:479-491

Falush D, Stephens M, Pritchard JK (2007) Inference of population structure using multilocus genotype data: dominant markers and null alleles. Mol Ecol Notes 7:574-578

Fér T, Vašák P, Vojta J, Marhold K (2007) Out of the Alps or Carpathians? Origin of Central European populations of Rosa pendulina. Preslia 79:367-376

Ferris C, King RA, Väinölä R, Hewitt GM (1998) Chloroplast DNA recognizes three refugial sources of European oaks and suggest independent eastern and western immigrations to Finland. Heredity 80:584-593 
Grivet D, Petit RJ (2002) Phylogeography of the common ivy (Hedera sp.) in Europe: genetic differentiation through space and time. Mol Ecol 11:1351-1362

Grivet D, Petit RJ (2003) Chloroplast DNA phylogeography of the horbeam in Europe: evidence for a bottleneck at the outset of postglacial colonization. Conserv Genet 4:47-56

Guisan A, Zimmermann NE (2000) Predictive habitat distribution models in ecology. Ecol Model 135:147-186

Hallden C, Nilsson NO, Rading IM, Sall T (1994) Evaluation of RFLP and RAPD markers in a comparison of Brassica napus breeding lines. Theor Appl Genetics 88:123-128

Hendrych R, Hendrychová H (1979) Preliminary report on the Dacian migroelemnt in the flora of Slovakia. Preslia 51:313-332

Heuertz M, Fineschi S, Anzidei M, Pastorelli R, Salvini D, Paule L, Frascaria-Lacoste N, Hardy OJ, Vekemans X, Vendramin GG (2004) Chloroplast DNA variation and postglacial recolonization of common ash (Fraxinus excelsior L.) in Europe. Mol Ecol 13:3437-3452

Hewitt GM (1999) Post-glacial recolonization of European biota. Biol J Linn Soc 68:87-112

Hijmans RJ, Cameron SE, Parra JL, Jones PG, Jarvis A (2005) Very high resolution interpolated climate surfaces for global land areas. Int J Climatol 25:1965-1978

Hurlbert SH (1971) The nonconcept of species diversity: a critique and alternative parameters. Ecology 52:577-586

Huson DH, Bryant D (2006) Application of phylogenetic networks in evolutionary studies. Mol Biol Evol 23:254-267

Ilnicki T, Joachimiak A, Sutkowska A, Mitka J (2011) Cytotypes distribution of Aconitum variegatum L. in Central Europe. In: Zemanek B (ed) Geobotanist and taxonomist, a volume dedicated to Professor Adam Zając on the 70th anniversary of his birth. Institute of Botany, Jagiellonian University, Kraków, pp 169-192

Jankovská V, Chromy P, Nižnianská M (2002) Šafarká-first palaeobotanical data of the character of the Last Glacial vegetation and landscape in the West Carpathians. Acta Palaeobot 42:39-50

Kelly MA, Buoncristiani J-F, Schlüchter C (2004) A reconstruction of the last glacial maximum (LGM) ice-surface geometry in the western Swiss Alps and contiguous Alpine regions in Italy and France. Eclogae Geol Helv 97:57-75

King RA, Ferris C (1998) Chloroplast DNA phylogeography of Alnus glutinosa (L.) Gaertn. Mol Ecol 7:1151-1161

Kotlík P, Deffontaine V, Mascheretti S, Zima J, Michaux JR, Searle JB (2006) A northern glacial refugium for bank voles (Clethrionomys glareolus). Proc Natl Acad Sci USA 103:14860-14864

Kožuharov S, Petrova A, Ehrendorfer F (1981) Evolutionary patterns in some brome grass species (Bromus, Gramineae) of the Balkan Peninsula. Bot Jahrb Syst 102:381-391

Kramp H, Huck S, Niketić M, Tomović G, Schmitt T (2009) Multiple glacial refugia and complex postglacial range shifts of the obligatory woodland plant Polygonatum verticillatum (Convallariaceae). Pl Biol 11:392-404

Krauss SL (2000) Accurate gene diversity estimates from amplified fragment length polymorphism (AFLP) markers. Mol Ecol 9:1241-1245

Kučera J, Tremetsberger K, Vojta J, Marhold K (2008) Molecular study of the Cardamine maritima group (Brassicaceae) from Balkan and Apennine Peninsulas based on amplified fragment length polymorphism (AFLP). Pl Syst Evol 275:193-207

Latałowa M, Ralska-Jasiewiczowa M, Miotk-Szpiganowicz G, Zachowicz J, Nalepka D (2004) Fagus sylvatica L. - Beech. In: Ralska-Jasiewiczowa M (ed) Late glacial and Holocene history of vegetation in Poland based on isopollen maps. W. Szafer Institute of Botany, Polish Academy of Sciences, Kraków, pp 95-104
Leroy SAG, Arpe K (2007) Glacial refugia for summer-green trees in Europe and south-west Asia as proposed by ECHAM3 time-slice atmospheric model simulations. J Biogeogr 34:2115-2128

Liepelt S, Cheddadi R, de Beaulieu J-L, Fady B, Gömöry D, Hussendörfer E, Konnert M, Litt T, Longauer R, TerhürneBerson R, Ziegenhagen B (2009) Postglacial range expansion and its genetic imprints in Abies alba (Mill.) —a synthesis from palaeobotanic and genetic data. Rev Palaeobot Palynol 153:139-149

Magri D (2008) Patterns of post-glacial spread and the extent of glacial refugia of European beech (Fagus sylvatica). J Biogeogr 35:450-463

Magri D, Vendramin GG, Comps B, Dupanloup I, Geburek T, Gömöry D, Latałowa M, Litt T, Paule L, Roure JM, Tantau I, Van Der Knaap WO, Petit RJ, De Beaulieu JL (2006) A new scenario for the Quaternary history of European beech populations: palaeobotanical evidence and genetic consequences. New Phytol 171:199-221

Manel S, Ceri Willams H, Ormerod SJ (2001) Evaluating presenceabsence models in ecology: the need to account for prevalence. J Appl Ecol 38:921-931

Meusel H, Jäger EJ, Weinert E (1965-1992) Vergleichende Chorologie der zentraleuropäischen Flora. Band 1-3. Gustav Fischer, Jena

Michl T, Huck S, Schmitt T, Liebrich A, Haase P, Budel P (2010) The molecular population structure of the tall forb Cicerbita alpina (L.) Wallroth (Asteraceae) supports the idea of cryptic glacial refugia in central Europe. Bot J Linn Soc 164:142-154

Mirek Z, Piękoś-Mirkowa H (2002) Trawy gór [Grasses of mountains]. In: Frey L (ed) Polska Księga Traw. Instytut Botaniki PAN, Kraków (in Polish), pp 125-139

Nei M (1973) Analysis of gene diversity in subdivided populations. Proc Natl Acad Sci USA 70:3321-3323

Nordborg M, Hu TT, Ishino Y, Jhaveri J, Toomajian C et al (2005) The pattern of polymorphism in Arabidopsis thaliana. PLoS Biol 3(7):e196

Paun O, Schönswetter P, Winkler M, IntraBiodiv Consortium \& Tribsch A (2008) Historical divergence versus contemporary gene flow: evolutionary history of the calcicole Ranunculus alpestris group (Ranunculaceae) in the European Alps and the Carpathians. Mol Ecol 17:4263-4275

Petit RJ, Aguinagalde I, Beaulieu JL, Bittkau C, Brewer S, Cheddadi R, Ennos R, Fineschi S, Grivet D, Lascoux M, Mohanty A, MullerStarck G, Demesure-Musch B, Palmé A, Pedro Marti J, Rendell S, Vendramin GG (2003) Glacial refugia: hotspots but not melting pots of genetic diversity. Science 300(5625):1563-1565

Pritchard JK, Stephens M, Donelly P (2000) Inference of population structure using multilocus genotype data. Genetics 155:945-959

Provan J, Bennett KD (2008) Phylogeographic insights into cryptic glacial refugia. Trends Ecol Evol 23(10):564-571

Ralska-Jasiewiczowa M, Nalepka D, Goslar T (2003) Some problems of forest transformation at the transition to the oligocratic/Homo sapiens phase of the Holocene interglacial in northern lowlands of central Europe. Veget Hist Archaeobot 12:233-247

Ralska-Jasiewiczowa M, Latałowa M, Wasylikowa K, Tobolski K, Madeyska E, Wright Jr HE, Turner C (2004) Late glacial and Holocene history of vegetation in Poland based on isopollen maps. In: W. Szafer Institute of Botany, Polish Academy of Sciences, Kraków

Rohlf FJ (2002) NTSYSpc: numerical taxonomy system, version 2.11a. Exeter Publishing, Ltd., Setauket

Roleček J (2005) Vegetation types of dry-mesic oak forests in Slovakia. Preslia 77:241-261

Ronikier M (2011) Biogeography of high-mountain plants in the Carpathians: an emerging phylogeographical perspective. Taxon 60:373-389 
Schiemann K, Tyler T, Widén B (2000) Allozyme diversity in relation to geographic distribution and population size in Lathyrus vernus (L.) Bernh. (Fabaceae). Plant Syst Evol 225:119-132

Schönswetter P, Tribsch A (2005) Vicariance and dispersal in the Alpine perennial Bupleurum stellatum L. (Apiaceae). Taxon $54: 725-732$

Šeffer J, Lasák R, Galavánek D, Stanová V (2002): Grasslands of Slovakia. Final report on National Grassland Inventory 1998-2002. Daphne, Institute of Applied Ecology, Bratislava

Sokal RR, Michener CD (1958) A statistical method for evaluating systematic relationships. Univ Kans Sci Bull 38:1409-1438

Stachurska-Swakoń A, Cieślak E, Ronikier M (2012) Phylogeography of subalpine tall-herb species in Central Europe: the case of Cicerbita alpina. Preslia 84:121-140

Stepansky A, Kovalski I, Perl-Treves R (1999) Intraspecific classification of melons (Cucumis melo L.) in view of their phenotypic and molecular variation. Plant Syst Evol 271:313-332

Sułkowska M, Gömöry D, Paule L (2012) Genetic diversity of European beech in Poland estimated on the basis of isoenzyme analyses. Folia Forest Polon Ser A 54:48-55

Sutkowska A, Mitka J (2008) RAPD analysis points to Old World Bromus species as ancestral to New World subgen. Festucaria. Acta Biol Cracoviensia Ser Bot 50:117-125

Sutkowska A, Mitka J, Glimos E, Warzecha T (2007) Phylogenetic relations among selected species of genus Bromus, subgenus Festucaria (Poaceae). In: Frey L (ed) Biological issues in grasses. W. Szafer Institute of Botany, Polish Academy of Sciences, Krakow, pp 169-179

Svenning JC, Normand S, Kageyama M (2008) Glacial refugia of temperate trees in Europe: insights from species distribution modelling. J Ecol 96:1117-1127

Swets JA (1988) Measuring the accuracy of diagnostic systems. Science 240(4857):1285-1293
Szafer W, Zarzycki K (eds) (1972) Szata roślinna Polski [Vegetation of Poland] 1. PWN, Kraków

Taberlet P, Fumagalli L, Wust-Saucy AG, Cossons JF (1998) Comparative phylogeography and postglacial colonization routes in Europe. Mol Ecol 7:453-464

Thuiller W (2004) Patterns and uncertainties of species' range shifts under climate change. Glob Change Biol 10:2020-2027

Thuiller W, Lafourcade B, Engler R, Araujo MB (2009) BIOMOD—a platform for ensemble forecasting of species distributions. Ecography 32:369-373

Tyler T (2002a) Geographical distribution of allozyme variation in relation to postglacial history of Carex digitata, a widespread European woodland sedge. J Biogeogr 29:919-930

Tyler T (2002b) Large-scale geographic patterns of genetic variation in Melica nutans, a widespread woodland grass. Plant Syst Evol 236:73-87

Tzedakis PC, Lawson IT, Frogley MR, Hewitt GM, Preece RC (2002) Buffered tree population changes in a quaternary refugium: evolutionary implications. Science 297(5589):2044-2047

Varela S, Lobo JM, Hortal J (2011) Using species distribution models in paleobiogeography: a matter of data, predictors and concepts. Palaeogeogr Palaeoclimatol Palaeoecol 310:451-463

Vekemans X, Beauwens T, Lemaire M, Roldan-Ruiz T (2002) Data from amplified fragment length polymorphism (AFLP) markers show indication of size homoplasy and of a relationship between degree of homoplasy and fragment size. Mol Ecol 11:139-151

Walter R, Epperson BK (2001) Geographic pattern of genetic variation in Pinus resinosa: area of greatest diversity is not the origin of postglacial populations. Mol Ecol 10:103-111

Willis KJ, Rudner E, Sümegi P (2000) The full-glacial forests of central and south-eastern Europe. Quat Res 53:203-213

Zając M, Zając A (2009) The geographical elements of native flora of Poland. In: Laboratory of Computer Chorology (ed) Institute of Botany, Jagiellonian University, Kraków 